International Journal of English Literature and Social Sciences
Vol-6, Issue-1; Jan-Feb, 2021

\title{
Symbolism in Young Good Man Brown
}

\section{Tian Xibo}

Dongfang College of Zhejiang University of Finance and Economics, China

Received: 02 Dec 2020; Received in revised form: 30 Jan 2021; Accepted: 15 Feb 2021; Available online: 27 Feb 2021

(C2021 The Author(s). Published by Infogain Publication. This is an open access article under the CC BY license

(https://creativecommons.org/licenses/by/4.0/).

\begin{abstract}
As one of the most talented Romantic novelists, Nathaniel Hawthorne is well-known for his Gothic and allegoric techniques. In his masterpiece Young Good Man Brown is a typical example to utilize this adroit method. The following article digs into symbolism utilized in the short story from the aspects of persons, things, scenes, the plot of the story etc. It is beneficial for us to make further studies on his works.
\end{abstract}

Keywords-Hawthorne; Young Good Man Brown; symbolism.

\section{INTRODUCTION}

Nathaniel Hawthorne, a 19th-century American writer of novels and short stories, is considered an important representative of Puritanism; symbolism and romanticism in American literature. He was imbued with an inquiring imagination, a meditative mind, and an unceasing interest in the ambiguity of man's being. He was interested in the lonely and dark side of man, and in the man's need to look into his own soul. Throughout his life, he wrote many works which espoused the complexities and sense of guilt of the human being. On first perusal of his tales and romances, one cannot fail to be overwhelmed by the black vision which these works reveal. This thesis discusses his main literary techniques, such as the psychological analysis and symbolism of Hawthorne, as reflected in the short story Young Goodman Brown. Hawthorne aims at exploring uncertainties of belief that trouble Brown's heart and soul. With the help of the minute psychological analysis and symbolism, Hawthorne exposes the dark side of human beings and society and manifests his sincere love of the world

As one of the most talented and essential American novelists and short story writers of the Romantic Period, Nathaniel Hawthorne was the first to initiate a new tradition in American literature, which was later called symbolic romance. Meanwhile, being regarded as an important representative who lived in the mid ninetieth century, Hawthorne was deeply affected by three systems of thoughts, that is to say, Puritanism, Transcendentalism and Mysticism, which are all reflected in his adroit utilization of the symbolic techniques in his Gothic prose style.

His famous short story Young Good Man Brown is a typical example of integrating the profound theme with the adroit techniques, which exposes to readers Hawthorne's psychological interpretation towards the vicious humanity and the growth of human beings through Young Good Man Brown's "journey in the forest". Using the background witchcraft to explore uncertainties of the belief that trouble a man's heart and soul, the story goes as follows:

Newly-married Goodman Brown, a Puritan who lived in the village of Salem departed his young dear wife to go on a "journey in the forest", which was indeed the witch's Sabbath that he was so reluctant to reveal. Later guided by a fellow traveler who was the reflection of the evil, he discovered that his ancestors were all faithful servants to the devil. He also came across a lot of prominent people there including the minister Goody Cloyse and Deacon Gookin, both of whom were his spiritual advisers. When he was about to be confirmed to the group, he heard the familiar voices of his villagers and even the voice of his wife Faith, who were all determined to make an appointment with the evil. Astonished by what he had seen and heard, he was tormented both morally and psychologically. He cried out to his wife "Look up to the Heaven, and resist the wicked one" (Nan, 2009), only to found himself alone in the forest. The next morning he came back to Salem village, with a dismal, gloomy and doubtful mood because he was never able to believe in 
goodness or piety again. He lived the rest of his life until the moment of his death.

In this short story, Hawthorne explores certain writing techniques into practice to create the characters, the most important of which is symbolism. Hawthorne's suspicious attitude toward the world determines his writing style as well as his position in American literature as a great master of symbolism. The essay deals with different symbolic aspects in his short story Young Good Man Brown.

\section{DIFFERENT SYMBOLS}

Symbolism is the use of description of some outward object in such a way that we shall discover in it some hidden meanings. The utilization of symbolism in the story can tell us as much as possible in as few words as possible. Frequently Hawthorne would make his story center around one essential object, such as a veil, a cross, a footprint or a birthmark which becomes symbolic of some moral quality or defect in his characters. In my essay, I think the following symbols are worthy to be mentioned.

\section{Name symbolism}

Our protagonist "Good Man" is in fact the Puritan's way of naming. Just like his name implies he is indeed a good man who is honest, sincere and loyal to God. Although he still could not resist the curiosity and temptation to finish the "journey in the forest" which further led to his disaster, he still felt somewhat guilty in his inner heart. His wife "Faith", the antagonist in our story is also the Puritan's way of naming, which symbolizes the loyalty to God and the love for God. Obviously the author chose those two names not at random but on purpose.

When Brown was asked why he was late for the appointment, his immediate reply was "Faith kept me back a while" (Yang, 2011). At that time his resolution to keep off the evil and be loyal to God has not yet changed. Later when he found out the hypocritical aspects of his town people he insisted that "With heaven above and Faith below, I will yet stand firm against the devil". Until eventually just before the end of the witch's Sabbath, he cried out "Look up to heaven and resist the wicked one"(Yang, 2011). At that time he was still making his efforts to hold back the hope and faith from the devil and wished to be led to the heaven by God. In this sense, Faith represented his faith toward human beings. He had hoped his wife Faith would be as faithful to God as he was, but it was ambiguous and mysterious whether he had kept up to the end, instead he became "a stern, sad, darkly meditative, distrustful, if not a desperate man" at the end of the story.

\section{Symbolic meaning of objects and actions}

More important than name symbolism is the symbolic use of objects and actions. In some stories these symbols will fit so naturally into the literal context that their symbolic value will not at first be apparent except to the most perceptive reader. In other stories-usually stories with a less realistic surface - they will be so central and so obvious that they will demand symbolical interpretation if the story is to yield the significant meaning. In the first kind of story, the symbols reinforce and add to the meaning. In the second kind of story they carry meaning.

\subsection{Symbolic meaning of objects}

\subsubsection{The fellow traveler, the maple stick and the tree}

In Young Good Man Brown, the maple stick of Brown's fellow traveler is an obvious token of evil. When it first appeared, it was described as "bore the likeness of a great black snake, so curiously wrought that it might almost be seen to twist and wriggle itself like a living serpent" (Nan, 2009). When Brown told the elder person about the virtue of the minister, the stick wriggled in order to refute Brown's views. In a sense, the man with the stick is the sign of Satan, the original sin in Bible, who tempted Adam and Eve to eat the Forbidden Fruits and brought the original sin to human beings in the shape of a serpent. And the maple stick itself degenerated into the leader of evil and the demon. Throughout the evening journey Brown was occupied by the stick and walked towards the evil. In a sense, the tree in the story can be said to be the forbidden tree in Bible.

\subsubsection{The pink ribbons}

The pink ribbons have always been the focus for critics which are worthy to be mentioned here. Having appeared three times in the short story the pink ribbons also have symbolic meanings. Scarlet often refers to sex while white refers to purity. The mixture of scarlet with white suggests neither total depravity nor innocence, but a psychological state in between. Tied like a label to the head of Faith, they represent the tainted innocence, the spiritual imperfection of all mankind. (Ferguson, 1969). Faith's ribbons are found in the evil forest and that is when Faith is really seen as an unclear person. Faith is also said to have committed adultery not only against Young Good Man Brown but also against God because she gave in to the likes of the devil. The ribbons provide a continuity between Faith as an ideal of religious fidelity and as partner in a witch's Sabbath (Levy, 2017). James Matthews thinks that the ribbons were rather worn on Brown's head than on Faith's head. They are embodied in the three crucial stages of Brown's psychological change (Levy, 2017).

The first time when Brown was about to leave his home, Faith with the pink ribbons looked very gracious, 
which indicated that she was pure. The second time the pink ribbons appeared was in the forest, when Brown heard the voice of Faith and beheld the pink ribbons falling from the sky as he cried "My Faith is gone", which indicates that the kindness and belief were taken away from both of them. The third time was the next morning when he was back to the village and Faith ran to kiss him joyfully with pink ribbons on her head. At the sight of the pink ribbons Brown felt hideous because he believed that everything was but evil. Generally speaking the pink ribbons were symbols of good and added bright color to a gloomy atmosphere. According to Able, "The pink ribbons seen in the forest may be merely a lustful projection of Good Man's depraved fancy, which wills wickness...even as it reluctantly departs from its forfeited innocence"(Levy, 2017).

\subsubsection{The Salem village}

Another thing worthy to be mentioned here is the Salem village. The village is the reflection of civilized lives of human beings, where there are moral and secular restrictions everywhere. So it represents the luminous side of human beings which is in contrast with the dark forest representing what Freud called "id", being composed of all kinds of desires. These desires are deeply hidden in the subconsciousness, which are forbidden by what Freud called "superego", that is to say, the social moral principles.

According to Freud, human characters are composed of three components, namely "id, ego and superego". The "id" represents the unconsciousness which is Brown's curiosity and desire for the evil whereas the "ego" stands for reason and circumspection, which is easily to be influenced by the outside world. According to Freud, the "superego" is the "representative of all moral restrictions, the advocate of the impulse toward perfection, in short it is as much as we have been able to apprehend psychologically of what people call the 'higher' things in human life" (Wilfred, 2014). During his "journey in the forest", the "id" and the "superego" are in conflict with each other all the time. Because of the disillusionment of his ideals, the power of the "id" is increasing while the power of the "superego" is decreasing with the decreasing of the power of the "ego". So at the temptation of the devil he stepped further and further into the forest to attend the witch's Sabbath. This is also the reflection of Calvinism and Puritanism when Nathaniel Hawthorne lived, which emphasizes all kinds of evils resulted from Adam and Eve's wrongdoings, for they were against God and ate the Forbidden Fruits.

\subsection{4 "Sunset" and "sunrise"}

Both "sunset" and "sunrise" in our short stories have symbolic meanings. "Sunset" heralds the forthcoming of the darkness, reflecting the inner evil of human's inner heart. It is also in contrast with "sunrise" which implies the luminosity, reflecting the maxims human beings must adhere to.

\subsubsection{Nature}

In a sense, the repeated "nature" in the story not only reflects the natural world, but also refers to Brown's "id". When Brown found his naïve Faith was also there in the witch's Sabbath, he was totally desperate. "The whole forest was peopled with frightful sound-The creaking of the trees, the howling of wild beasts and the yell of Indians; while sometimes the wind tolled like a distant church bell, and sometimes gave a broad roar around the traveler, as if all nature were laughing him to scorn". When the evil was preaching he even claimed that "Evil is the nature of mankind. Evil must be your only happiness". This is also in accordance with Hawthorne's attitude towards good and evil, "Evil is the nature of mankind" (Yang, 2011).

Freud also thought that during the development of personality, children are inclined to have "Electra complex" or "Oedipus complex". So boys would regard their fathers as their enemy of lovers, instead their mother was regard as their ideal lover. This can also be embodied in the story. The moment his "id" and "superego" are in conflict with each other and he was at a loss whether to be baptized or not, "the shape of his own dead father beckoned him to advance, looking downward from a smoke-wreath, while a woman, with dim features of despair, threw out her hand to warn him back. Was it his mother" (Nan, 2009). In his subconsciousness, his father is considered his enemy, who would push him to death. On the contrary, his mother was thought of as his lover and safeguard God. So he imagined that his father was calling him to join the community in the forest even as his mother would hold him back.

\subsection{Symbolic meaning of actions}

\subsubsection{Laughter}

Throughout this short story, the word "laughter" appears many times. According to Coldirion, "Hawthorne uses laughter to mark his protagonists' epiphanies and to emphasize points of thematic conflict... a Satan-figure, the elder traveler, initiates the dreadful laughter...[which] mocks Brown's naïve belief in the innocence of the town people, as he wonders aloud how he could face his minister after such a night's journey into the evil...The transformation of Faith's scream into a laugh of acceptance as she joins a similarly evil gathering in progress...intensifies the personalizes Brown's perception 
of conflict. Thus propelled by crescendos of laughing, Brown sees the pink ribbons fall, and his awareness of the conflict between good and evil is incomplete. He gives himself over to a new perspective. " After Faith's apparent union with Satan, Brown "initiates the horrible laughter, as the Satan-figure first did, which confirms not only his awareness of the opposition of good and evil forces, but also his union with, acceptance of, and even leadership in the devil viewpoint. The demoniac: "Utterly possessed by the devil, he (Brown) yields to the conviction that the world is given over to sin" (Levy, 2017).

\subsubsection{The "journey in the forest"}

In Young Good Man Brown, the theme of the story is the realistic reflection of the life of human beings. Brown's "journey in the forest" is actually "the journey in his heart". The "journey deep into the dark forest" can be said to be "the journey deep into one's inner heart", especially for such a naïve and immature man like Brown who was experiencing the anguish growth. The experience of Brown was compressed in a nightmare in the forest, which is also the reflection of the so-called world view that "The life of the human beings is like a dream". So the genuine unification of the contents and the form are fully embodied in this works, furthermore the theme is hereby extended.

At the beginning of the story, Brown was firmly faithful to truth, kindness and beauty. Although he could not resist the temptation of the curiosity, he still felt somewhat reluctant, for his heart was fully occupied by loyalty and faith. Even though he stepped on the journey, he still firmly resolved to resist the temptation and was determined that "after this one night, I'll cling to her skirts and follow her to heaven".

But after he stepped into the forest and came into contact with the evil, he proved to be temporarily firm in belief. Tortured with the news never heard before that his grandfather had ever lashed a Quaker woman so smartly through the streets of Salem and his father had set fire to an Indian village, he was somewhat doubtful, but he still went on with his journey with firm belief, though not very long. In his naïve eyes, his ancestors and he were certainly not to be wrongdoers and they could not tolerate this kind of evil.

Then came the first austere torture for him. He was astonished to find out his two spiritual advisers Goody Cloyse and Deacon to be friends of his fellow traveler, who is the token of evil. His first response was to shrink back from the evil journey so that he could have nothing to worry about to face them the next morning. Before he could get a firm foothold the second torture came before him. He woefully found another two advises of his, also went to attend the witch's Sabbath. Then he could not tolerate the attack any more and doubt "whether there was a heaven above" (Nan, 2009). He was on the verge of collapse both mentally and psychologically. However he did not give up but decided to use "Faith" as sole mentor.

But this mentor did not last long before the third attack came upon him. He desperately found his dear wife Faith was also there to attend the party. He was totally collapsed. "There was no good on earth, and sin is but a name, come, devil! For to thee is this world given" (Jiao, 2014). At that time, he was neither fearful nor hopeful. Just before he was confirmed to the group he cried out "Look up to heaven and resist the wicked one" (Nan, 2009), but then he was alone in the forest.

Up till now his dream came to an end. Brown's dream in forest was an important stage for his growth. It is also the junction in his life, one leading to the sunlight place, the other one leading to the marsh. It was a pity he had chosen the wrong one before he could understand the real meaning of human life, which led to his disaster. But it was possible for everyone else to make the same choice, for he had no choice but to escape.

\subsubsection{The symbolic choosing of the scene}

Besides, Hawthorne's choosing of the scene is also a symbolic method. The story took place in Salem, which is notorious for its witchcraft in New England. The evening forest also highlighted the mysterious and gloomy atmosphere. It was during the dark time and the dark place that Brown met the devil. What's more, in depicting the forest, Hawthorne adroitly chose such words as "gloomy" or "wicked" in order to exploit the theme of the story.

Goodman Brown came to the meeting where he saw grave, reputable and pious people of the state council, the church-members of Salem village, and his elders and betters in the past. But the scenery was appalling:a pulpit was surrounded by four blazing pines, their tops aflame, their stems untouched, like candles at an evening meeting. The mass of foliage was on fire, blazing high into the night and fitfully illuminating the field. As the lurid light arose and fell, a numerous congregation alternately shone forth, then disappeared, in shadow. The apparition quivered to and fro between gloom and splendor. The descriptions reinforced the horrifying circumstances. Everything was enveloped in the visionary and gloomy atmosphere beneath which there gathered many hideous souls.

Hawthorne made an uncertain dreamy situation in which the spirit of the human being was probed. In front of the altar;" the good shrank not from the wicked, nor were the sinners abashed by the saints.' From the dark figure Brown realized: "How hoary-bearded elders of the church have whispered want on words to the young maids of their households: how many a woman, eager for widow' $s$ weeds, has given her husband a drink at bedtime, and left 
him sleep his last sleep in her bosom;how beardless youths have made haste to inherit their fathers' wealth and how fair damsels-blush not, sweet ones-have dug little graves in the garden, and bidden me, the sole guest, to an infant's funeral'.

The ugly nature of humanity was thoroughly exposed. Brown penetrated the hypocritical characters of the decent people and hideous behaviour concealed by the "marvelous" excuse. Nothing was good throughout the world, and '"the whole earth one stain of guilt, one mighty blood spot". Seduced by the fiend, Brown stepped forth from the shadow of trees, and behaved as if in the charge of the devil. But at this moment, Brown still hesitated, he dil not forget warning Faith against the evil, , Look upto heaven, and resist the witched one'. The cruel fact smashed all the good expectations of Brown, and he lost trust in everything. Many essential changes had taken place in him. When he returned to the lives as they used to. Brown shrank from the good old minister and Goody Cloyse as if to avoid anathema. Even to his lovely wife Faith, he looked sternly and sadly into her face, and passed on without a greeting. Observed by Brown, all the sacred were infected by the evil germ. He could not listen to a holy psalm on the Sabbath day because an anthem of sin rushed loudly upon his ear and drowned all the blessed strain, and the minister' s holy speech was not instructive but rubbish. He always woke up at midnight, scrowled and muttered to himself. He became depressed and extremely suspicious, his brain became addled day and night, and he ended the rest of his life in sorrow. Brown changed from good into evil, sinking into the abyss step by step. Concealed bythe night, hideous misdeeds were being performed, people lost their conciousness dancing with the fiend. So in the story, the night symbolizes the dark spiritual side of man.

\subsubsection{The symbolic meaning in the plot of the story}

The symbolic meaning is also embodied in Hawthorne's working out the plot of the story. At the end of the story, the author has provided a question "Had Brown fallen asleep in the forest and only dreamed a wild dream of a witch-meeting" (Nan, 2009). Anyway the evening journey in the forest is a symbol on the whole. It does not refer to the realistic trip but symbolizes the exploration of the spirit and the realization of the darkness hidden in the human being. Just as Hawthorne's story The Birthmark suggests "Evil is man's birthmark, something he is born with" (Chen, 2007).

\section{CONCLUSION}

The symbol, as a means of expression, reflects the styles of the writer. Hawthorne employs the description of the symbolic circumstances and characters to strengthen the moral of his works, and gives rise to his peculiar artistics.

With respect to all the above, this thesis has dealt with Hawthorne's literary techniques as reflected by Young Good man Brown. On the basis of the his apt use of symbolism, Hawthorne makes this simple story reputable and shows his genius as a remarkable American short story writer of this time. There is no doubt that Hawthorne's penetrating moral vision; intense symbolism and stylistic subtlety have had a wide-ranging influence on the other writers. In the same century, William Faulkner and some Gothic novelists clearly showed their indebtedness to him. If his reputation is still rising, it is indeed as it should be. As Henry James put it, "Among the men of imagination he will always have his niche".

\section{REFERENCES}

[1] Abel, Darrel. The Moral Picturesque:Studies in Hawthorne's Fiction. Indiana: Purdue UP, 1988.

[2] Bunge, Nancy. Nathaniel Hawthorne: A Study of the Short Fiction. New York: Twayne, 1993.

[3] Chen Mei. "Psychoanalysis and Symbolism: On Nathaniel Hawthorne's Young Good man Brown". Journal of Wudang. 1997 (17).

[4] Ferguson, J.M., Jr. Hawthorne's Young Good Man Brown. Explicator 28(Dec. 1969):Item 32.

[5] Levy, L. B.. The Problems of Faith in Young Good Man Brown. Journal of English and Germanic Philology. 2017 (3).

[6] L. G. Wilfred \& Labor Earle. A Handbook of Critical Approaches to Literature. Beijing: Foreign Language Teaching and Research. 2014.

[7] Yang Qishen. Freud's Personality Theory: Enlightenment of Children Psychological Health. Journal of Fujian Normal University. 2011 (2).

[8] Nan Jianchong. British and American Fiction. Xi' an: Shanxi Normal Universities Press. 2009.

[9] Jiao Lidong. About Symbolism of Young Good Man Brown. Heihe Journal.2014(6).

[10] Ren Xiaojin, Cheng Baoyan. New Analysis of Young Good Man Brown. Foreign Literature Studies. 2008(4). 